Beata Jeżyńska

\title{
Organizacja rolniczej działalności wytwórczej w ramach klastra
}

\section{Uwarunkowania społeczno-ekonomiczne współdziałania przedsiębiorców w ramach kalstrów}

W obliczu narastających fali kryzysu gospodarczego Unia Europejska sformułowała nowe założenia reform długoterminowych, które ujęte zostały w Komunikacie Komisji z dnia 3 marca 2010 r.: Europa 2020. Strategia na rzecz inteligentnego i zrównoważonego rozwoju sprzyjającego włączeniu społecznemu². Strategia Europa 2020 obejmuje trzy wzajemnie ze sobą powiązane priorytety rozwoju gospodarczego. Przede wszystkim zakłada rozwój inteligentny, który zmierza do wdrażania zasad gospodarki opartej na wiedzy i innowacji. Nadto, rozwój ma mieć charakter zrównoważony, czyli taki, w którym gospodarka powinna efektywnie korzystać z zasobów naturalnych, zachowywać warunki wytwarzania przyjazne środowisku i poprawiać konkurencyjność, a także sprzyjać włączeniu społecznemu poprzez wysoki poziom zatrudnienia, spójność społeczną i terytorialną.

Nowe zasady produkcji rolno-spożywczej ujęte zostały w odrębnym dokumencie, jakim jest Komunikat Komisji do Parlamentu Europejskiego, Rady, Europejskiego Komitetu Ekonomiczno-Społecznego i Komitetu Regionów z dnia 18 listopada 2010 r.: WPR do 2020 r.: sprostać wyzwaniom przyszłości związanych z żywnością, zasobami naturalnymi oraz aspektami terytorialnymi ${ }^{3}$. Komisja przyjęła, że rolnictwo jest integralną częścią gospodarki i europejskiego społeczeństwa. Osłabienie czy ograniczenie działalności rolnej spowodowałoby spadek PKB i utratę miejsc pracy w powiązanych z rolnictwem sektorach gospodarki - przede wszystkim w obrębie łańcucha dostaw żywności, który jest zależny od podstawowego sektora rolnego w zakresie dopływu surowców. Pociągnęłoby także negatywne skutki dla sektorów działalności pozarolniczej, takich jak turystyka, transport oraz usługi publiczne i lokalne. Na sile przybrałby także negatywny proces wyludniania tere-

Uniwersytet Marii Curie-Skłodowskiej w Lublinie.

Bruksela 3.3.2010 KOM (2010) 2020 wersja ostateczna.

Bruksela 18.11.2010 KOM (2010) 627 wersja ostateczna. 
nów wiejskich. Z tych też względów, w opinii Komisji, należy kontynuować zapoczątkowany proces reform wspólnej polityki rolnej, tak by zapewnić wzrost konkurencyjności produkcji, wytwarzanie bezpiecznej żywności, ochronę środowiska, przeciwdziałanie zmianom klimatu, utrzymanie bioróżnorodności, uzyskanie równowagi terytorialnej i społecznej oraz wieloaspektowe powiązanie rolnictwa z innymi działami gospodarki. Celem zasadniczym powinien być - jednoznacznie wynikający ze Strategii Europa 2020 - zrównoważony, inteligentny i sprzyjający włączeniu społecznemu rozwój europejskich obszarów wiejskich oraz konkurencyjna i innowacyjna produkcja rolna.

\section{Prawne pojęcie oraz zasady funkcjonowania klastrów}

2.1. W kontekście tak sformułowanych najnowszych programów rozwoju społeczno - gospodarczego Unii Europejskiej oraz oczekiwanych rezultatów wdrażanych przemian, szczególnego znaczenia nabrała problematyka organizacji nowoczesnych i innowacyjnych form współdziałania gospodarczego, jakimi są klastry ${ }^{4}$.

W literaturze przedmiotu pojęcie klastru najczęściej definiowane jest, w myśl założeń sformułowanych przez M.E. Portera, jako geograficzne skupisko wzajemnie ze sobą powiązanych firm, wyspecjalizowanych dostawców, jednostek świadczących usługi, firm działających w pokrewnych sektorach związanych $\mathrm{z}$ nimi instytucji (takich jak jednostki normalizujące, stowarzyszenia branżowe), w poszczególnych dziedzinach konkurujących ze sobą, ale również współpracujących ${ }^{5}$. Poszerzenie współpracy w ramach tak utworzonej sieci o jednostki naukowe, władze lokalne i regionalne oraz inne organizacje wspierające zlokalizowane w pewnej bliskości, pozwala rozbudować sferę oddziaływania, poprawia przepływ informacji, usprawnia działania rynkowe i marketingowe, koordynuje kierunki zmian i rozwoju, a w efekcie poprawia konkurencyjność i innowacyjność danej działalności

W literaturze przedmiotu dość często zamiennie stosowane jest pojęcie klastru, inicjatywy klastrowej, organizacji klastrowej czy polityki klastrowej. Pojęcia te nie są jednak synonimami. Inicjatywa klastrowa rozumiana jest jako działania na rzecz rozwoju i wzrostu konkurencyjności zmierzające do utworzenia klastra obejmujące przedsiębiorstwa, administrację oraz środowisko nauki. W ramach inicjatyw klastrowych często powstają organizacje klastrowe. Sa to podmioty prawne zajmujące się koordynacją inicjatyw klastrowych, w tym opracowania zasad współpracy, uczestnictwa i dostępu do wspólnej infrastruktury bądź działań. Organizacja klastrowa (sieć współpracy) jako koordynator korzysta ze wsparcia finansowego ze środków publicznych oraz jest podmiotem dokonującym redystrybucji uzyskanych środków na rzecz uczestników klastrów. Polityka klastrowa definiowana jest natomiast jako szczególne działanie administracji na rzecz wspierania klastrów. Może przybierać różne formy i dążyć od różnych celów. Polityki klastrowe w większości przypadków są wdrażane przez konkretne programy na szczeblu krajowym lub regionalnym. Zob. O. Solvell, G. Linqvist, C. Ketels: The Cluster Initiative Greenbook, Stockholm 2003, s. 34 i nast. oraz analizę Instytutu Badań nad Gospodarką Rynkową: Wykorzystanie koncepcji kalstrów dla kształtowania polityki innowacyjnej I technologicznej państwa. Rekomendacja dla polityki stymulowania rozwoju klastrów w Polsce, Gdańsk 2009, www.ibngr.edu.pl

$5 \quad$ M.E. Porter: Porter o konkurencyjności, Warszawa 2001, s. 246 . W literaturze podejmowane się także próby nieco innego sposobu zdefiniowania klastra. We wszystkich jednak definicjach wskazać można cechy charakterystyczne, jakimi są: koncentracja geograficzna, współpraca, koncentracja sektorowa, specjalizacja oraz współzależność współpracujących ze sobą jednostek. Przegląd stanowisk prezentuje J.Pasieczny, Czynniki i uwarunkowania procesu tworzenia i rozwoju klastrów, (w:) Klastry jako narzędzia lokalnego i regionalnego rozwoju gospodarczego, pod red. E. Bojar, Lublin 2006, s. 89-95. 
gospodarczej w konkretnym regionie. I właśnie takie założenia stanowią istotę europejskiej koncepcji klastra jako formy innowacyjnego współdziałania gospodarczego $^{6}$.

Po raz pierwszy koncepcja klastrów określona została w decyzji Parlamentu Europejskiego i Rady nr 1639/2006 ustalającej Program ramowy na rzecz konkurencyjności i innowacji na lata 2007-20137 . W dokumentach statuujących najnowsze założenia rozwoju gospodarczego Komisja uznała szczególne znaczenie klastrów, jako mechanizmów zapewniających łączenie podmiotów gospodarczych i instytucji naukowych umożliwiające szybsze wprowadzanie wiedzy na rynek oraz uznała klastry jako jeden z dziewięciu strategicznych priorytetów dla realizacji szeroko zakrojonej europejskiej strategii innowacyjnej ${ }^{8}$. Jednocześnie Komisja powołała Europejskie Obserwatorium Klastrów oraz Europejską Grupę do spraw Polityki Klastrowej, których zdaniem jest gromadzenie, przetwarzanie i udostępnianie danych dotyczących funkcjonowania klastrów w państwach Unii Europejskiej ${ }^{9}$.

2.2. Przepisy polskiego prawa nie definiują pojęcia klastra jako formy organizacji współpracy gospodarczej. Jedynie postanowienia § 27 ust. 2 rozporządzenia Ministra Rozwoju Regionalnego w sprawie udzielania przez Polską Agencję Rozwoju Przedsiębiorczości pomocy finansowej w ramach programu „Innowacyjna gospodarka" formułują pojęcie powiązania kooperacyjnego, pod którym rozumie się zgrupowanie działające w określonym sektorze niepowiązanych ze sobą przedsiębiorców, prowadzących działalność innowacyjną oraz organizacji badawczych i instytucji otoczenia biznesu, które ma na celu stymulowanie działalności innowacyjnej przez promowanie intensywnych kontaktów, korzystania ze wspólnego zaplecza technologicznego, wymiany wiedzy i doświadczeń, przyczyniania się do transferu technologii, tworzenia sieci powiązań oraz rozpowszechniania informacji wśród przedsiębiorców wchodzących w składnego ugrupowania ${ }^{10}$.

6 M. Szewczak, Rozwój inicjatyw klastrowych w Polsce. Problemy administracyjno-prawne, (w:) Administracja publiczna i gospodarka 5 lat po przystapieniu Polski do Unii Europejskiej, pod red. M. Szewczak, K. Grabczuk, Lublin 2010, s. 29-43.

7 Art. 13 decyzji 1639/2006/WE Parlamentu Europejskiego i Rady z dnia 24 października 2006 r. ustanawiająca Program ramowy na rzecz konkurencyjności i innowacji (2007-2013) Dz.Urz. UE L 310 z 9.11.2006, s. 15. Komunikat Komisji nt. Wykorzystanie wiedzy w praktyce: Szeroko zakrojona strategia innowacyjna dla UE, Bruksela 13 września 2006 r. COM (2006) 502 wersja ostateczna. Docelowo powstawać powinny klastry ponadnarodowe - globalne. Zob. Komunikat Komisji do Rady, Parlamentu Europejskiego, Europejskiego Komitetu Ekonomiczno - Społecznego i Komitetu Regionów: W kierunku światowej klasy klastrów Unii Europejskiej, Bruksela 17 października 2008 r. COM (2008) 652 wersja ostateczna.

9 Decyzja Komisji nr 2008/824/WE z dnia 22 października 2008 r. ustanawiająca europejska grupę ds. polityki klastrowej Dz.Urz. UE L 288 z 30.10.2008, s. 7 oraz www.clusterobserwatory.eu

$10 \S 27$ ust. 2 rozporządzenia Ministra Rozwoju Regionalnego z dnia 7 kwietnia 2008 r., Dz.U. Nr 68, poz. 414 ze zm. cytowane dalej jako „rozporządzenie w sprawie wsparcia finansowego PARP”. Należy zaznaczyć, że istnieje wiele definicji klastrów tworzonych najczęściej z uwzględnieniem celu ich utworzenia i wykorzystania. $Z$ ekonomicznego punktu widzenia definiowanie klastrów zmierza do wskazania wpływu klastrów na konkurencyjność. Inne definicje odnoszą się od innych celów, takich jak np. określenie reguł prawnych dla uzyskania wsparcia z funduszy publicznych. Tak właśnie ma to miejsce w odniesieniu do definicji powiazania kooperacyjnego (klastra) z powołanego § 27 rozporządzenia Ministra Rozwoju Regionalnego. 
Przyjęte dla potrzeb finansowego wsparcia pojęcie powiązania kooperacyjnego odpowiada cechom charakterystycznym klastra i znajduje zastosowanie przede wszystkim w odniesieniu do innowacyjnych klastrów przemysłowych. Takie też formy współdziałania powstają najczęściej. Problematyka tworzenia i funkcjonowania klastrów wiejskich jest podejmowana znacznie rzadziej ${ }^{11}$, mimo że najnowsze założenia rozwoju obszarów wiejskich przyjęte przez Unię Europejską w programie WPR do 2020 r.: sprostać wyzwaniom przyszłości związanych z żywnością, zasobami naturalnymi oraz aspektami terytorialnymi, zakładają poprawę konkurencyjności i innowacyjności działań właśnie przez tworzenie i propagowanie przedsięwzięć wspólnie realizowanych, w tym także w ramach klastrów.

\section{Klastry produktów rolnych}

W polskich realiach gospodarczych tworzenie klastrów na obszarach wiejskich napotyka na daleko idące utrudnienia.

Zasadnicze wynikają z braku tradycji i woli współpracy zarówno między samymi producentami rolnymi, jak i między producentami a innymi podmiotami rynku rolnego. Jeszcze dalej idące są wątpliwości natury prawnej, które koncentrują się w trzech płaszczyznach. Po pierwsze, czy działalność rolnicza może zostać uznana za działalność innowacyjną. Po drugie, czy na gruncie obowiązujących przepisów można producentów rolnych uznać za przedsiębiorców, a prowadzoną przez nich działalność wytwórczą za gospodarczą, stosownie do wymagań tworzenia powiązania kooperacyjnego, oraz czy producenci rolni mogą korzystać ze wsparcia finansowego w ramach programu Innowacyjna Gospodarka. Zaś po trzecie, należy rozważyć znaczenie grup producentów rolnych i ich organizacji wyższego stopnia w tworzeniu i funkcjonowaniu klastrów związanych z produkcją rolno-spożywczą.

\subsection{Produkcja rolnicza jako działalność innowacyjna}

Pojęcie innowacji produktowej zakłada, że produkt innowacyjny prezentuje najwyższe parametry jakościowe i w możliwie najwyższym stopniu spełnia wymagania klienta. W szczególności wprowadza w produktach zmiany związane $\mathrm{z}$ dostosowaniem do standardów ochrony środowiska, podwyższa parametry zdrowotne, dostosowuje produkt do potrzeb i oczekiwań indywidualnego klienta. W takim ujęciu produktami innowacyjnymi w sektorze rolnictwa mogą być zarówno produkty rolno-spożywcze wytwarzane metodami tradycyjnymi, zwłaszcza produkty ekologiczne, tradycyjne czy regionalne, jak i wytwarzane przy zastosowaniu najnowszych

11 B. Szymoniuk, Klastry na terenach wiejskich oraz ich wpływ na rozwój regionalny, (w:) Wiedza, innowacyjność, przedsiębiorczość a rozwój regionów, pod red. A. Jewtuchowicz, Łódź 2004, s. 273 i nast.; M. Adamowicz, D. Guzal-Dec: Współpraca samorządu gminnego z przedsiębiorstwami i organizacjami pozarządowymi na przykładzie wybranych gmin wiejskich województwa lubelskiego, (w:) Sieci proinnowacyjne w zarządzaniu regionem wiedzy, pod red. E. Bojar, J. Stachowicza, Lublin 2008, s. 121-133. 
osiągnięć biotechnologii, jak to ma miejsce w przypadku produktów żywnościowych genetycznie zmodyfikowanych (GMO). Innowacyjne mogą też być tradycyjne produkty żywnościowe, których skład zostaje wzbogacony lub zmodyfikowany dla potrzeb profilaktyki zdrowotnej ${ }^{12}$. Oczywiście, cechy innowacyjności są tu diametralnie różne. W przypadku GMO innowacyjność polega na wykorzystaniu najnowszych technologii. Podobnie w odniesieniu do produktów specjalnego przeznaczenia żywieniowego, gdzie innowacyjność z reguły związana jest z wdrożeniem wyników najnowszych badań naukowych i postępu technologicznego. W odniesieniu do produktów tradycyjnych innowacyjność polega na wytwarzaniu wytworów o najwyższych parametrach zdrowotnych i organoleptycznych, gwarantujących zaspokojenie wymagań biologicznych i zdrowotnych konsumentów oraz wytwarzanych w procesie produkcyjnym korzystnym dla środowiska oraz zachowującym istniejące ekosystemy (powszechnie zwanych produkcją ekologiczną) ${ }^{13}$.

Teza, w myśl której produkcja rolno-spożywcza uwzględniająca wymogi zdrowotne konsumenta oraz zrównoważone korzystanie z zasobów środowiskowych ma szczególną postać innowacji, zyskała akceptację na forum europejskim. Uznanie przez Unię Europejską za priorytetowe działań na rzecz ochrony zdrowia publicznego oraz bezpieczeństwa środowiska, zachowania bioróżnorodności spowodowało traktowanie działań zmierzających do realizacji wskazanych celów jako innowacji ekologicznych. Powoływana już decyzja Parlamentu Europejskiego i Rady 1639/2006/WE zdefiniowała innowacje ekologiczne jako wszelkie formy innowacji zmierzające do znacznego i widocznego postępu w kierunku realizacji celu w postacie zrównoważonego rozwoju poprzez ograniczenie oddziaływania na środowisko lub osiąganie większej skuteczności i odpowiedzialności w zakresie bezpieczeństwa zdrowotnego oraz wykorzystywania zasobów naturalnych, w tym energii i wody. Postanowienia decyzji zwracają uwagę, że pojęcie ekologicznych innowacji ma charakter ewolucyjny, a zatem programy wspierające gospodarkę innowacyjną muszą uwzględniać możliwość uznania za innowacyjne ekologicznie działania w sferach dotychczas nie podejmowanych ${ }^{14}$. Począwszy od 2009 r., w ramach programu Europe INNOVA powołana została Platforma Eko-innowacje (Eco-IP), której zadaniem jest promowanie rozwiązań proekologicznych. Eco-IP składa się z czterech partnerstw: BIOCHEM - promujących wytwarzanie oraz wprowadzanie do obro-

Przykładowo wskazać można na margaryny ze sterolami roślinnymi kontrolującymi poziom cholesterolu, jogurty o wzbogaconej florze bakteryjnej poprawiającymi trawienie czy podnoszącymi odporność zdrowotna, a także produkty o obniżonej zawartości tłuszczu, bezcukrowe, bezglutenowe i inne.

Zagadnienia zasad produkcji i wprowadzania do obrotu produktów ekologicznych omawiają m.in.: I. Canfora: Rolnictwo ekologiczne w prawie wspólnotowym, „Przegląd Prawa Rolnego” 2008, nr 2, s. 115-126; K. Leśkiewicz, Prawna ochrona terminów używanych od oznaczania produktów rolnictwa ekologicznego, „Przegląd Prawa Rolnego” 2008, nr 2, s. 127-145, tejże; Jednostki certyfikujące jako podmioty kontrolujące i nadzorujące w rolnictwie ekologicznym, „Przegląd Prawa Rolnego” 2009, nr 1, s. 79-95; tejże; Sankcje w rolnictwie ekologicznym, „Przegląd Prawa Rolnego” 2010, nr 1, s. 51-71; M.A. Król, Prawne podstawy obrotu produktami rolnictwa ekologicznego w świetle rozporządzenia Rady WE 834/2007, (w:) Obrót gospodarczy w prawie rolnym, pod red. B. Jeżyńskiej, Lublin 2009, s. 84-105.

Zob. pkt 25 Preambuły oraz art. 14 Decyzji nr 1639/2006/WE. 
tu bioproduktów wykonanych z odnawialnych surowców, takich jak rośliny i drzewa; INNOWATER - obejmujące działania w zakresie zrównoważonej gospodarki wodno-ściekowej; Remake - wspierające działania na rzecz recyklingu i efektywnego wykorzystania dostępnych zasobów naturalnych oraz EcoTroFood - działające na rzecz ochrony środowiska w przemyśle produktów spożywczych. Celem programu jest komercjalizacja innowacyjnych ekologicznych rozwiązań technicznych w zakresie produkcji i usług na rynku spożywczym, tak by radykalnie zmniejszyć negatywne oddziaływanie na ekosystemy oraz zwiększyć ochronę bezpieczeństwa zdrowotnego konsumentów żywności. Program EcoTroFood zakłada współdziałanie $\mathrm{z}$ innymi programami skierowanymi na ochronę środowiska i zrównoważony rozwój ekosystemów ${ }^{15}$.

W takim ujęciu zadania z zakresu ekoinnowacji odnoszą się do niemal wszystkich działalności wytwórczych w rolnictwie i mogą, a nawet powinny być wdrażane w procesie wytwórczym. Tym samym działalność rolnicza, a co najmniej pewne jej procesy prowadzone w ramach rolnictwa zrównoważonego, ekologicznego, a nawet tradycyjnego, ale realizowanego z zachowaniem wymagań zasady cross compiliance (zwłaszcza zaś ochrony środowiska, zasobów wodnych, dobrej kultury rolnej, dobrostanu zwierząt oraz bezpieczeństwa zdrowotnego produktów) mogą mieć charakter działań innowacji ekologicznej. Niewątpliwie innowacyjny charakter ma także produkcja biopaliw należących do odnawialnych źródeł energii, a zatem zmniejszająca negatywne oddziaływanie na środowisko naturalne oraz ograniczająca nadmierne zużycie istniejących zasobów naturalnych ${ }^{16}$.

\subsection{Producent rolny jako przedsiębiorca - uczestnik klastra}

Ocena, czy działalność rolnicza jest w prawie polskim działalnością gospodarczą, a w konsekwencji, czy producent rolny jest przedsiębiorcą, który może być uczestnikiem klastra (powiązania kooperacyjnego), nastręcza zdecydowanie więcej wątpliwości. Problematyka statusu prawnego producenta rolnego w sferze obrotu gospodarczego nie jest nowa i była obszernie sygnalizowana w literaturze przedmiotu $^{17}$. Zagadnienia stąd wynikające zostaną przeto w tym miejscu jedynie syntetycznie zasygnalizowane.

Wyróżnienie przedsiębiorcy - tak w sferze prawa publicznego, jak i prywatnego - dokonywane jest według kryterium podmiotowego oraz przedmiotowego. Zgodnie z treścią art. $43^{1} \mathrm{kc}$. przedsiębiorcą jest osoba fizyczna, osoba prawna i jed-

15 Eco-Innovation Platform - Europe INNOVA, www.proinno-europe.eu

16 Produkcję biopaliw uznaje za działalność innowacyjną decyzja nr 1639/2006/WE. Zob. pkt $46-54$ Preambuły oraz art. 37-40 cytowanej decyzji.

17 Zagadnienia związane ze statusem prawnym producenta rolnego w sferze obrotu gospodarczego sa przedmiotem opracowań monograficznych. Zob. P. Blajer, Koncepcja prawna rolnika indywidualnego w prawie polskim na tle porównawczym, Kraków 2009 oraz B. Jeżyńska, Producent rolny jako przedsiębiorca, Lublin 2008 oraz powołana tam literatura. Dalsze uwagi stanowią wycinek prezentowanych w cytowanej monografii zagadnień. 
nostka organizacyjna, która nie jest osobą prawną, ale której ustawa przyznaje zdolność prawną, prowadząca we własnym imieniu działalność gospodarczą lub zawodową.

W prawie polskim działalność rolnicza nie została jednolicie zdefiniowania. Ustawodawca dla określenia czynności gospodarczych producentów rolnych posługuje się na gruncie ustaw szczególnych różnorodnymi pojęciami, takimi jak rolnictwo, produkcja rolna lub rolnicza, rolnicza działalność wytwórcza, czy prowadzenie gospodarstwa rolnego. Dla potrzeb obrotu gospodarczego zdecydowanie największe znaczenie ma konstruowane na gruncie obowiązujących ustaw pojęcie wytwórczej działalności rolniczej, definiowane albo przez wskazanie na biologiczne procesy wytwórcze, jakimi jest produkcja roślinna, zwierzęca i rybna, albo przez wskazanie poszczególnych kategorii upraw, chowu czy hodowli, niekiedy nawet z określeniem minimalnych cykli biologicznego wzrostu czy rozrodu ${ }^{18}$. Tak konstruowane definicje, choć pod względem treści niejednolite, pozwalają na wskazanie cech charakterystycznych dla pojęcia wytwórczej działalność rolniczej. Otóż pojęcie to służy do charakterystyki aktywności gospodarczej (zawodowej, profesjonalnej) producenta rolnego, bez względu na organizacyjno-prawną formę, w jakiej jest prowadzona. Aktywność ta ma naturę wytwórczą, przy czym zakres czynności produkcyjnych zawsze obejmuje co najmniej wytwarzanie produktów w stanie naturalnym we własnym procesie produkcyjnym. Tym samym pojęcie rolniczej działalności wytwórczej zakłada aktywne współistnienie odpowiednio zorganizowanej jednostki produkcyjnej, podmiotu prowadzącego stosowną działalność przy wykorzystaniu składników takiej jednostki oraz efektu końcowego, jakim jest produkt rolny przeznaczony do obrotu gospodarczego ${ }^{19}$.

Na gruncie obowiązujących przepisów ocena, czy tak rozumiana rolnicza działalność wytwórcza jest działalnością gospodarczą, dokonywana jest na gruncie przepisów ustawy o swobodzie działalności gospodarczej ${ }^{20}$. W treści art. 2 ustawy o swobodzie działalności gospodarczej zawarte jest wyliczenie poszczególnych rodzajów działalności gospodarczych, które pomija działalność rolniczą, zaś w art. 3 ustawa zastrzega, że do sfery działalności rolniczej nie stosuje się przepisów powołanej ustawy. Niejasnym jest przeto, czy działalność rolnicza nie jest w ogóle działalnością gospodarczą, czy też jest to działalność gospodarcza, ale o charakterze szczególnym ${ }^{21}$. Jednoznaczne i niebudzące wątpliwości rozstrzygnięcie tej wątpliwości, wielokrotnie sygnalizowanej w piśmiennictwie i orzecznictwie, nie jest niestety możliwe do czasu interwencji ustawodawcy. Ustawowe dookreślenie sytua-

18 Tak zwłaszcza krajowe ustawy podatkowe.

19 R. Budzinowski, Prawne pojęcie działalności rolniczej, „Prawo i Administracja” 2003, t. 2, s. 167.

20 Ustawa z dnia 2 lipca 2004 r. o swobodzie działalności gospodarczej, tekst jedn. Dz.U. z 2007 r. Nr 155 , poz. 1095, zwana dalej ustawą o swobodzie działalności gospodarczej. 21 A. Walaszek-Pyzioł, Swoboda działalności gospodarczej, Kraków 1994, s. 28; M. Waligórski: Nowe prawo dzia-
łalności gospodarczej, Poznań 2001, s. 90. 
cji prawnej producentów rolnych jest bardzo pilne z wielu względów - ubezpieczeniowych, podatkowych, społecznych, ale przede wszystkim z uwagi na konieczne unowocześnienie procesów wytwórczych w rolnictwie oraz włączenie producentów rolnych w najnowsze struktury współdziałania gospodarczego. Uzasadnieniem do podjęcia działań legislacyjnych są także oczekiwania Unii Europejskiej związane z wdrażaniem najnowszych założeń Strategii Europa 2020, zakładającej podejmowanie innowacyjnych działań natury gospodarczej także w sferze produkcji rolnej.

W sferze organizacji klastrów niejednoznaczna sytuacja prawna producentów rolnych uwidacznia się na gruncie przepisów powoływanego już rozporządzenia w sprawie wsparcia finansowego Polskiej Agencji Rozwoju Przedsiębiorczości (PARP), na podstawie którego powiązania kooperacyjne mogą korzystać ze środków programu Innowacyjna Gospodarka. Otóż uczestnikiem takiego powiązania mogą być, co od zasady, przedsiębiorcy. Tym samym do oceny organów PARP należeć będzie, czy tworzący klaster uczestnicy - producenci rolni - mogą lub nie mogą być uznani za przedsiębiorców, a w konsekwencji, czy mogą lub nie, ubiegać o wsparcie finansowe. Dalsze ograniczenie wynika wprost z treści $\S 4$ ust. 3 pkt 3 lit a, b rozporządzenia w sprawie wsparcia finansowego PARP, w myśl którego pomoc nie może być udzielona na działalność związaną z produkcją pierwotną produktów rolnych oraz jej przetwarzaniem i wprowadzaniem od obrotu, jeżeli wysokość pomocy jest uzależniona od ceny lub ilości produktów zakupionych od producenta surowców, lub gdy przyznanie pomocy zależy od przekazania jej w całości lub w części producentom surowców. Powołane ograniczenie, choć nie uniemożliwia co do zasady uczestniczenie producentów rolnych w powiązaniu kooperacyjnym, to jednak z uwagi na to, że ich udział w sposób istotny wpływa na zasady przydzielania i dystrybucji pozyskiwanych środków publicznych, może stanowić zasadniczą barierę $\mathrm{w}$ tworzeniu nowoczesnych form współpracy z udziałem producentów rolnych w Polsce.

\subsection{Grupy producentów rolnych jako uczestnicy klastrów}

Na gruncie prawa polskiego sytuację prawną organizacji producentów rolnych kształtują przepisy ustawy o grupach producentów rolnych i ich związkach oraz o zmianie innych ustaw ${ }^{22}$ wraz z rozporządzeniem Rady (WE) nr 1234/2007 z dnia 22 października 2007 r. ustanawiające wspólną organizację rynków rolnych oraz przepisy szczegółowe dotyczące niektórych produktów rolnych (,,rozporządzenie o jednolitej wspólnej organizacji rynku" $)^{23}$.

Ustawa o grupach producentów oraz ich związkach sformułowała generalne zasady tworzenia oraz uznawania (rejestracji) zrzeszeń producentów warunkują-

22 Ustawa z dnia 15 września 2000 r. Dz.U. Nr 88, poz. 983 ze zm., zwana dalej ustawą o grupach producentów lub u.g.p.

23 Dz.Urz. UE L 299 z 16.11.2007, s. 1. 
cych ich dopuszczenie do uczestniczenia lub kontrolowania mechanizmów wspólnej organizacji rynku. W myśl art. 2 ustawy o grupach producentów rolnych w celu dostosowania produkcji rolnej do warunków rynkowych, poprawy efektywności gospodarowania, planowania produkcji ze szczególnym uwzględnieniem ilości, jakości, koncentracji podaży oraz organizowania sprzedaży produktów rolnych, a także ochrony środowiska może być utworzona grupa producentów, która jest zrzeszeniem producentów rolnych, będącym przedsiębiorcą posiadającym osobowość prawną.

Grupy producentów rolnych z uwagi na cele, jakie realizują, zasady funkcjonowania w obrocie gospodarczym oraz status zrzeszonych podmiotów, mają cechy wskazujące na ich szczególną przydatność do współdziałania w ramach klastrów. Barierą jest natomiast powszechnie znana słabość istniejących grup producentów rolnych, niechęć do zrzeszania się i wspólnego uczestniczenia w regułach obrotu gospodarczego. U podstaw takiego stanu rzeczy legły zróżnicowane okoliczności. Zasadnicze znaczenie mają zaszłości historyczne, sprowadzające się do ciągle jeszcze żywej pamięci o próbach socjalizacji pracy na wsi, której przejawem była obowiązkowa współpraca oraz przejmowanie gospodarstw rolnych na własność Skarbu Państwa. Powstałe wówczas poczucie konieczności utrzymania własności gospodarstwa, wzajemna nieufność w relacjach społeczno-gospodarczych oraz wewnętrzna konkurencja przetrwały do chwili obecnej. Nie bez znaczenia jest także słaba znajomość obowiązujących regulacji prawnych - nader niejasnych i niespójnych, trudności przy wyborze formy prawno-organizacyjnej oraz procedur rejestracyjnych, wyborczych, sprawozdawczych i związanych z wpisami sądowymi, wysoki poziom wymagań produkcyjnych kształtowanych na poziomie europejskim, szybko zmieniające się oczekiwania konsumentów oraz bardzo skomplikowane relacje gospodarcze. Widoczna jest także pewna nieufność i rezerwa wobec wszelkich nowych rozwiązań organizacyjnych. Stąd też pojawiły się propozycje, by dla propagowania form współdziałania wykorzystać znane producentom od lat rolnicze zrzeszenia branżowe. $\mathrm{U}$ podstaw formułowanych propozycji legło założenie, że z uwagi na szczególne znacznie wspólpracy i zrzeszania rolników nie należy a priori rezygnować z żadnych prawnie określonych form współdziałania, choćby nawet regulacje decydujące o funkcjonowaniu poszczególnych struktur nie były wolne od ułomności. Forma współdziałania, jaką są zrzeszenia branżowe producentów, uregulowana jest postanowieniami ustawy z dnia 8 października 1982 r. o społeczno-zawodowych organizacjach rolników ${ }^{24}$. Zgodnie $\mathrm{z}$ ustawową definicją zrzeszenie to jest dobrowolną, niezależną i samorządną społeczno-zawodową organizacją reprezentującą i broniącą praw i interesów rolników indywidualnych specjalizujących się w określonej gałęzi produkcji roślinnej lub zwierzęcej. Rolnicze zrzeszenia branżowe mogą łączyć się w związki rolniczych zrzeszeń branżowych, a w przypadku nie- 
przystąpienia do takiego związku - zrzeszają się we właściwym krajowym związku branżowym. Terenem działalności związków może być rejon, województwo, okręg lub teren całego kraju. W formie prawnej związku rolniczych zrzeszeń branżowych funkcjonuje niemal sześćdziesiąt podmiotów. Na szczeblu krajowym, a także na forum europejskim w ramach COPA/COGECA ponad dwadzieścia wiodących związków reprezentowanych jest przez Federację Branżowych Związków Producentów Rolnych $^{25}$. Zrzeszenia, w myśl przepisów ustawy, mają osobowość prawną i mogą prowadzić działalność gospodarczą.

Za uwzględnieniem tej formy współpracy w ramach klastrów przemawia prosta konstrukcja tworzenia i funkcjonowania, szeroki katalog uprawnień i zadań, jakie mogą być realizowane przez zrzeszenie, stricte branżowy i terytorialny charakter organizacji oraz utrwalona forma współpracy wykorzystywana w bardzo różnych warunkach i dla różnych potrzeb. Należy jednak zwrócić uwagę, że przepisy regulujące działalność zrzeszeń uchwalane były w zupełnie innych realiach gospodarczych, stąd akceptując tę formę współdziałania ze względów, o których była mowa, wypada postulować dokonanie nowelizacji istniejących przepisów, tak by dostosować ich brzmienie od warunków wolnorynkowych i reguł wspólnej polityki rolnej.

\section{Związki grup producentów rolnych oraz organizacje międzybranżowe}

Przepisy Unii Europejskiej dla umocnienia znaczenia organizacji producentów i uzyskania stabilności rynku dopuszczają, a nawet popierają tworzenie stowarzyszeń organizacji producentów rolnych oraz podmiotów międzybranżowych.

\subsection{Związki grup producentów rolnych}

Ustawa o grupach producentów rolnych dopuściła możliwość tworzenia związków grup producentów danego produktu lub grupy produktów w celu reprezentowania wspólnych interesów. Związki grup producentów mogą podejmować zorganizowane działania, zmierzające do zaopatrzenia w środki produkcji, przechowywania i wstępnego przetwarzania produktów oraz koordynacji ich zbytu. A także dla promocji produktów, analizy rynku, obsługi prawno-księgowej oraz reprezentowania zrzeszonych grup przed organami administracji samorządowej i rządowej. Nie ma też przeszkód, by organizacje lub ich zrzeszenia zawierały umowy natury gospodarczej, tworząc ramy szeroko rozumianej współpracy czy kooperacji dla realizacji wspólnie określonego celu. Umowy, o których mowa, mogą mieć charakter stricte produkcyjny lub pozaprodukcyjny, zwłaszcza gdy dotyczą działań promocyjnych, marketingowych, lobbystycznych czy naukowo-badawczych. Realizacja zbieżnych interesów może też sprowadzać się do wymiany świadczeń, realizacji wspólnych 
przedsięwzięć, podziału lub uzgodnienia sfer działania czy też synchronizacji działań ${ }^{26}$. Zakres zadań jednoznacznie wskazuje na adekwatność organizacji producentów rolnych w zakresie współpracy organizowanej w ramach klastrów.

\subsection{Międzybranżowe organizacje producentów rolnych}

Szczególną przydatność dla tworzenia klastrów produktów rolnych wykazują organizacje międzybranżowe producentów rolnych. Organizacje te tworzone są w krajach UE w celu kształtowania instytucjonalnych powiązań producentów z innymi podmiotami gospodarczymi działającymi na rynku rolnym, przede wszystkim przetwórczymi oraz handlowymi, w celu organizacji obrotu produktami rolnymi oraz ochrony konsumentów. W zależności od zasięgu działania mogą one mieć charakter organizacji regionalnych lub ponadregionalnych.

Przepisy polskiej ustawy o grupach producentów rolnych i ich związkach oraz o organizacji niektórych rynków rolnych, odmiennie od przepisów Unii Europejskiej, nie przewidują organizowania się producentów w organizacjach międzybranżowych. Cele i zadania właściwe dla międzybranżowych organizacji wspólnotowych powierzono izbom gospodarczym ${ }^{27}$. Przepis art. 26 ustawy o grupach producentów rolnych dopuścił tworzenie izb gospodarczych przez grupy i ich związki oraz przedsiębiorców prowadzących działalność przetwórczą lub handlową w zakresie wskazanego produktów lub grupy produktów. Izby gospodarcze umożliwiają poszerzenie gospodarczych wpływów organizacji producentów rolnych oraz ukształtowanie relacji i współdziałania między grupami i ich związkami a zrzeszonymi w Izbie przedsiębiorcami prowadzącymi działalność przetwórczą lub handlową.

$\mathrm{Z}$ uwagi na potrzeby organizacji klastrowych utworzenie izby gospodarczej przez grupy producentów oraz inne współdziałające z nimi gospodarczo podmioty ma znaczenie szczególne. Izby, w myśl § 27 ust. 5 rozporządzenia o wsparciu finansowym PARP, mogą bowiem pełnić funkcje koordynatora powiązania kooperacyjnego (klastra), a tym samym występować o uzyskanie środków wsparcia finansowego z programu Gospodarka Innowacyjna oraz dokonywać ich redystrybucji między uczestników klastra.

\section{Konkluzje}

O ile sytuacja prawna producenta rolnego jako przedsiębiorcy pozostaje nie od końca jasna, a jednoznaczna interpretacja nie będzie możliwa do czasu zasadniczej ingerencji ustawodawcy, o tyle nie budzi wątpliwości status prawny grup producentów rolnych oraz ich organizacji wyższego stopnia, uznanych wprost w treści 
przepisów za przedsiębiorcę. Grupy producentów rolnych ujmowane są w literaturze ekonomicznej jako integracja pionowa w rolnictwie. Pod pojęciem integracji pionowej rozumie się formę więzi ekonomicznej i produkcyjnej między podmiotami wytwarzającymi dany produkt od surowca do produktu finalnego ${ }^{28}$. Łączenie producentów wytwarzających ten sam produkt, a więc działających w tym samym poziomie wytwarzania, ułatwia promocję i marketing produktów, dystrybucję, negocjowanie cen i warunków zbytu. Umożliwia też wspólne korzystanie z zaplecza technicznego, zwłaszcza sprzętu rolniczego, efektywne wykorzystanie majątku trwałego, a w konsekwencji zwiększenie zasobów finansowych, uzyskanie przeznaczonych dla organizacji producentów środków wsparcia finansowego oraz obniżenie kosztów produkcji. W takim ujęciu grupy mogą stać się ogniwem integrującym łańcuch produkcyjny od surowca do produktu finalnego.

Z punktu widzenia organizacji i funkcjonowania klastrów w produkcji rolniczej możliwości grup producentów rolnych są nie do przecenienia. Po pierwsze, nie budzi wątpliwości, iż są przedsiębiorcami, a zatem bezspornie uprawnionymi do uczestniczenia w klastrach gospodarczych.

Wskazując na znaczenie grup dla tworzenia nowoczesnych form współdziałania gospodarczego, należy jeszcze zasygnalizować najnowsze zamiany w zakresie funkcjonowania grup na jednolitym rynku rolnym. Od kilku lat wokół przyszłości wspólnej polityki rolnej toczy się dyskusja, w której podnoszone są zalety oraz wady dotychczasowego jej funkcjonowania. Przedmiot dyskusji uległ wyraźnemu skonkretyzowaniu po dokonaniu średniookresowej oceny wspólnej polityki rolnej zwanej health check. Za wymagający najpilniejszych zmian uznano system interwencji rynkowej, wskazując, że dotychczasowy rozbudowany katalog wspólnotowych i państwowych środków stymulowania rynku musi ulec ograniczeniu do poziomu tzw. siatki bezpieczeństwa, uruchamianej tylko w okolicznościach poważnych klęsk czy destabilizacji rynków. Natomiast w zwykłych warunkach wytwarzania i wprowadzania od obrotu produktów rolnych uprawnienia w zakresie stabilizacji rynków oraz kształtowania podaży realizować mogą organizacje producentów działające w ramach poszczególnych rynków rolnych. Stąd w prezentowanych stanowiskach poszczególnych państw członkowskich co do perspektywy dalszych zmian wspólnej polityki rolnej po roku 2013 dominujący jest pogląd, w myśl którego należy ujednolicić system funkcjonowania organizacji producentów rolnych i ich stowarzyszeń we wszystkich sektorach produkcji na wzór przyjętych w sektorze owoców i warzyw. Ujednolicone zasady funkcjonowania byłyby najbardziej korzystne, gdyż nie różnicowałyby sytuacji prawnej producentów w zależności od produktu lub grupy produktów, jakie są wytwarzane. Nadto efektywnie stabilizowałyby ryn1998, s. 383. 
ki wszystkich branż, zmierzając do celu polegającego na dostosowaniu podaży i popytu poprzez wielkość produkcji, wspieranie restrukturyzacji poszczególnych branż oraz zapobieganie i zarządzanie ryzykiem oraz kryzysami ${ }^{29}$. Oznacza to przyznanie szczególnych uprawnień organizacjom producentów w sferze kształtowania podaży i popytu oraz bezpieczeństwa rynku produktów rolnych. W takim ujęciu grupy producentów rolnych w organizacji klastra uzyskują szczególną pozycję.

29 Szczególnie mocno potrzeby takich zmian akcentuje stanowisko rządu Francji oraz Włoch. Zob. A. Szymecka: Analiza proponowanej reformy Wspólnej Polityki Rolnej (tzw. health check) z punktu widzenia interesów Włoch, (w:) Reforma Wspólnej Polityki Rolnej z 2008 r. (health check) z punktu widzenia interesów wybranych państw członkowskich, Warszawa 2008, s. 23-24; P. Bryła: Analiza proponowanej reformy Wspólnej Polityki Rolnej (tzw. health check) z punktu widzenia interesów Francji, (w:) Reforma Wspólnej Polityki Rolnej z 2008 r. (health check) z punktu widzenia interesów wybranych państw członkowskich, Warszawa 2008, s. 117-124. 


\section{Organization of agricultural production activities within the cluster}

Key words: cluster, innovation, economic cooperation, socio - economic development

In recent programs of socio - economic development of the European Union the issue of the organization of modern and innovative forms of economic cooperation, such as clusters gained special meaning. In literature, the term cluster is usually defined as a geographic cluster of interrelated companies, specialized suppliers, service providers, firms in related sectors associated with them institutions, in particular fields that compete and also cooperate with each other. Expanding cooperation within the so-formed network and implementing scientific institutions, local and regional authorities and other support organizations located in a certain proximity, allow to expand the sphere of influence, improve information flow, business operations and marketing, coordinate directions of change and development, resulting in improved competitiveness and innovativeness of the business in a particular region. And these are the assumptions that are the essence of the European concept of the cluster as an innovative form of economic cooperation.

The issue of rural clusters is discussed much less frequently than issues related to industrial clusters. Recent objective to improve the competitiveness and rural development policies adopted by the European Union in WPR to 2020: cope with future challenges related to food, natural resources and territorial aspects, involve improving the competitiveness and innovation activities through the creation and promotion of projects jointly implemented, including those fulfilled within clusters.

In the Polish economic realities the development of clusters in rural areas faces a far-reaching difficulties. The essential difficulties result from the lack of tradition and willingness to cooperate among agricultural producers as well as producers and other subjects of agri - food market. Even more far-reaching are the legal uncertainties, which are concentrated in three areas. First, whether agricultural activity may be regarded as innovative activity. Second, whether on the basis of existing rules can agricultural entrepreneurs be regarded as producers and their manufacturing activity as a business activity, according to the requirements of forming a cluster and can agricultural producers benefit from financial assistance under the program of Innovative Economy. And thirdly, you should consider the importance of agricultural producer groups and their organizations in the creation and functioning of clusters associated with the agri - food production. 